International Journal of Biology, Pharmacy and Allied Sciences (IJBPAS) 'A Bridge Betueen Caboratory and QRendor'

\author{
WWW.ijbpas.com
}

\title{
A GEOGRAPHICAL STUDY OF SOLID WASTE MANAGEMENT IN
} SOLAPUR CITY

\author{
V. C. DANDE ${ }^{1 *}$ AND S. S. RAUT ${ }^{2}$ \\ 1: Assistant Professor, Department of Geography, D. B. F. Dayanand College of Arts and Science, Solapur
} 2: C.B. Khedgis College, Akkalkot

"Corresponding Author: Dr. V.C. Dande: E Mail: vedande@gmail.com Received $10^{\text {th }}$ June 2021; Revised $11^{\text {th }}$ July 2021; Accepted 20 ${ }^{\text {th }}$ Aug. 2021; Available online $15^{\text {th }}$ Jan. 2022 https://doi.org/10.31032/IJBPAS/2022/11.1.1030

\begin{abstract}
City Solid Waste (MSW) has turned into a significant issue in significant urban communities all over India just as world. The issue of strong waste is likewise impacting the Solapur city. Hence, the current review was under taken to give data about assortment and removal of strong waste. The review is concentrated to examine the current status of Municipal Solid Waste Management (MSWM) in Solapur city. To do the review a definite overview was done on existing offices of Solid Waste Management (SWM) like labor assets and the board frameworks. The significant information was gotten from Solapur Municipal Corporation and individual field visits. The review uncovers that there are a few lacunas in existing strong waste administration framework in Solapur city based on Municipal Solid Waste (Management and Handling) rules, 2016.

\section{INTRODUCTION:}

Strong waste administration is a term that is utilized to allude to the method involved with gathering and treating strong squanders. It additionally offers answers for reusing things that don't have a place with trash or garbage. However long individuals have been living in settlements and neighborhoods, trash or strong

\section{Keywords: Municipal solid waste, Geographical Study etc.}

waste has been an issue. Squander the executives is regarding how strong waste can be changed and utilized as a significant asset. Strong waste administration ought to be embraced by every single family including the entrepreneurs across the world. Industrialization has brought a great deal of beneficial things and awful things also. One of
\end{abstract}


the adverse consequences of industrialization is the production of strong waste.

As indicated by Britannica, "Strong waste administration, the gathering, treating, and discarding strong material that is disposed of on the grounds that it has filled its need or is presently not valuable. Ill-advised removal of civil strong waste can make unsanitary conditions, and these conditions thus can prompt contamination of the climate and to flare-ups of vector-borne sickness - that is, illnesses spread by rodents and bugs."

- Objective :

To study present states of Solid waste Management in Solapur City.

Study Area:-

For present investigation Solapur City is selected as a study area. It is one of the important cities of Maharashtra.
The Solapur City is located between

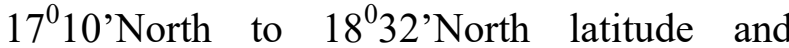
$75^{\circ} 42^{\prime}$ East to $75^{0} 15^{\prime}$ East longitude. It covers an area of $179 \mathrm{Sq}$. Km. It is located in the Bhima basin just before the Bhima River leaves Maharashtra to enter in to Karnataka. The National Highway No. 9 and 13 and State Highway pass through Solapur, City (Map No. 1).

Solapur is situated 550 meters over the mean ocean level. Sina River, which is a feeder of Bhima River, streams close to the southwestern part, of Solapur City. The environment of the city is dry consistently, because of its inland area. In 1993-1994 Municipal Corporation breaking point of Solapur was expanded and 11 Villages were incorporated as far as possible.

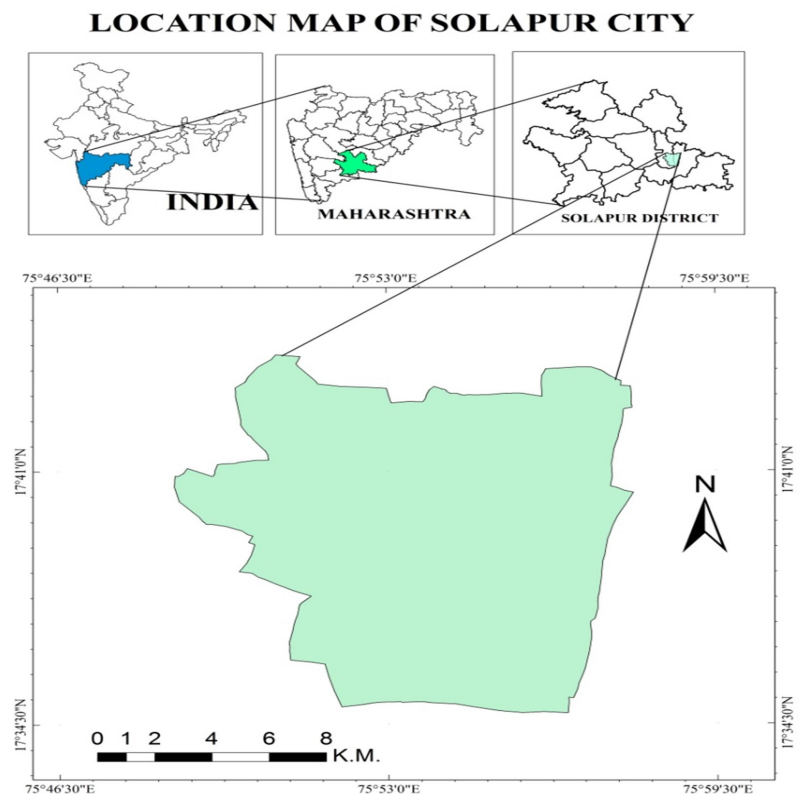

Map No. 1 


\section{Data base and Methodology:}

The present study based on primary and secondary data. Researcher conducts a survey to understand present collection and disposal system of solid waste. Secondary data collect through publications of various government organizations. the collected data analysed give table interpretation and the result presented through table and map.

\section{Interpretation:}

The growth rate of population in the Solapur city recorded $0.4 \%$ and total area is $179 \mathrm{Sq} . \mathrm{Km}$. This area divided in 6 Zones with 16 or 17 Words. Zone No. 3 have lowest area and Zone No. 5 registered highest area in sq. km. (46.999). According to No. of Households there is a Normal change in numbers as expected Zone no. 3 have lowest households which is 30776 and Zone No. 2 having largest no. of households denoted 33618 .

Table 1: Zone wise details of Area, Population and Total Household in Solapur City

\begin{tabular}{|c|c|c|c|}
\hline Zone & No. Wards & No. of House Households & Area in sq. km. \\
\hline Zone 1 & 16 & 31148 & 33.189 \\
\hline Zone 2 & 17 & 33618 & 25.674 \\
\hline Zone 3 & 16 & 30776 & 11.585 \\
\hline Zone 4 & 16 & 31297 & 22.522 \\
\hline Zone 5 & 16 & 31116 & 46.999 \\
\hline Zone 6 & 17 & 32645 & 44.097 \\
\hline
\end{tabular}

Source: Solapur City Sanitation Plan, Final Draft, 2011.

Table 2: Zonewise Collection of Solid Waste

\begin{tabular}{|c|c|c|}
\hline Zone & Numbers of Hand carts & Solid Wasted Generated (MTD) \\
\hline Zone 1 & $\mathbf{8}$ & $\mathbf{7 0}$ \\
\hline Zone 2 & 6 & $\mathbf{7 5}$ \\
\hline Zone 3 & 12 & $\mathbf{6 5}$ \\
\hline Zone 4 & 10 & $\mathbf{6 5}$ \\
\hline Zone 5 & 16 & $\mathbf{7 0}$ \\
\hline Zone 6 & $\mathbf{8}$ & $\mathbf{4 2 0}$ \\
\hline Total & 60 &
\end{tabular}

Source: Solapur City Sanitation Plan. Final Draft. 2011

Total Solid Waste is generated $420 \mathrm{MT} /$ day in the study area. Zone no. 2 is highest contributor in total generated waste having only 6 hand carts which is very crucial to collect the waste.

In Solapur city 350 to 420 ton/day solid waste almost generated form that 300 ton is collected and remaining 50 ton waste is processed as per SWM Rules 2016. Presently Solid Waste collected through Ghanta Gadis having capacity is $350 \mathrm{Kg}$. to $550 \mathrm{Kg}$. All these Ghanta Gadis transfer their loads on four stations constructed under smart city project. From these four major centers heavy load 16 road comactors having capacity 8 to 10 tons collect this solid waste material to Solapur Bio-Energy System Pvt. Ltd. Plant which is established on Tuljapur Road in northern part of Solapur City. 
Table 3: No. of Vehicles and their Capacity

\begin{tabular}{|c|c|c|}
\hline Vehicle Type & Number of Vehicles & Capacity of Vehicles \\
\hline Ghantagadis & 200 & $\mathbf{3 5 0}-\mathbf{5 5 0}$ in $\mathbf{~ k g}$. \\
\hline Road Compactor & 16 & $\mathbf{8 - 1 0}$ Ton \\
\hline Seggregation Capsules & $\mathbf{8}$ & $\mathbf{1 8}$ Ton \\
\hline
\end{tabular}

Source : Revised Action plan for Control of air pollution in non-attainment cities of Maharashtra-Solapur municipal corporation. 2019

\section{Solid Waste Processing Plants:}

In Solapur city solid waste material processed by solapur municipal corporation on the Tuljapur Roads plant. The plant have 55 acres land out of this 46 acres land used for dumping of this solid waste and reaming 9 acres utilized for Bio Energy Plant. This plant segregated organic fraction of solid waste and generate energy \& the remaining is used for composting. Non-compostible waste like plastic is used in trial based Road Construction. The road of $2 \mathrm{~km}$. made from confiscated plastic at Bhavani peth in the Solapur City.

\section{CONCLUSION:}

Solapur city is a leading urban center not only in Maharashtra but in India hence; it is included in Smart City project of central government. Study area has 6 Zones but only four major collection centers of Solid Waste. According to population and area have to improvement the transport facility and collection of solid waste is necessary.

\section{REFERENCES:}

[1] Brockerhoff, M. (1999): "Urban Growth in Developing Countries: A Review of Projections and Predictions, Population and Development Review, Vol. 25, No. 4, pp.757-778.

[2] SWMR, (2000); State of Vermont Agency of natural resources Department of environmental conservation, Solid Waste Management Rules-2000.

[3] Kumar, S. and Gaikwad, S.A., (2004): "Municipal Solid Waste Management in Indian Urban Centres: An Approach for Betterment", Urban Development Debates in the New Millennium, Edited by K.R. Gupta, Atlantic Publishers \& Distributors, New Delhi, pp.100-111.

[4] R. Kavitha and P. Subramanian, (2007): Effect of Enriched Municipal Solid Waste Compost Application on Growth, Plant Nutrient Uptake and Yield of Rice, Journal of Agronomy, 6(4): pp. 586-592.

[5] SMC, (2010); Final Draft, Solapur City Sanitation Plan, Solapur Municipal Corporation, Solapur.

[6] SMC, (2011); Final Draft, Solapur City Sanitation Plan, Solapur Municipal Corporation, Solapur.

[7] R. K. Annepu (2012): Sustainable Solid Waste Management in India, Waste to 
energy and Technology council

Columbia University, New York.

[8] B.L.Chavan, N.S. Zambare, (2013): “A Case Study on Municipal Solid aste anagement in Solapur City, Maharashtra, India, International Journal of Research in Civil Engineering, Architecture \& Design Volume 1, Issue 2, pp. 46-53.

[9] SMC (2013);

http://www.solapurcorporation.com., A report.

[10] Solid Waste management Rules -2016 vikaspedia.

[11] Utkarsh Paatel, (2019): Solid Waste management in Indai, ICRIER, New Delhi.

[12] A. Kumar \& A. Agrawal (2020): Recent Trends in Solid Waste Management Status, Challenges, and potential for the Future Indian Cities - A review, Current Research in Environmental Sustainability, pp. 1-19.

[13] Colon, M. and Fawcett, B., (NY), "Community-based Household Waste Management: Lessons Learnt from EXNORA $^{\text {ec }}$,Zero Waste Management Scheme in Two South Indian
Cities",Habitat International, in press (Elsevier Publication).

[14] Sajja, G., Mustafa, M., Phasinam, K., Kaliyaperumal, K., Ventayen, R., \& Kassanuk, T. (2021). Towards Application of Machine Learning in Classification and Prediction of Heart Disease. 2021 Second International Conference On Electronics And Sustainable Communication Systems (ICESC).

https://doi.org/10.1109/icesc51422.2021. 9532940

[15] Veluri, R., Patra, I., Naved, M., Prasad, V., Arcinas, M., Beram, S., \& Raghuvanshi, A. (2021). Learning analytics using deep learning techniques for efficiently managing educational institutes. Materials Today: Proceedings. https://doi.org/10.1016/j.matpr.2021.11.4 $\underline{16}$

[16] C.M. Thakar, S.S. Parkhe, A. Jain et al., 3d Printing: Basic principles and applications, Materials Today: Proceedings, https://doi.org/10.1016/j.ma tpr.2021.06.272 